\title{
External Morphology and Female Genitalia of Ethmia candidella (Lepidoptera: Ethmiidae) Recorded for the First Time from Erzurum (Turkey)
}

\author{
Muhammed TATAR $^{1 *}$, Göksel TOZLU ${ }^{2}$, Erol ATAY $^{3}$
}

\begin{abstract}
Ethmia candidella (Alphéraky, 1908) samples recorded for the first time from Erzurum (Turkey) were collected with aspirator through the cracks and slits in Populus alba bodies in Atatürk University Campus in September 2017-2018. A total of 21 female individual were obtained. Specimens were dissected and prepared female genitalia and wings slides in the laboratory. The external morphology and female genitalia of $E$. candidella were described in detail. In addition, eggs from fertilized females under the microscope were obtained.
\end{abstract}

Keywords: Lepidoptera, Ethmiidae, Ethmia candidella, external morphology and female genitalia, Erzurum, Turkey.

\section{Erzurum (Turkey)'dan İlk Kez Kaydedilen Ethmia candidella (Lepidoptera: Ethmiidae)'nın Dış Morfolojisi ve Dişi Genitalyası}

$\ddot{\mathbf{O} z}$

Erzurum'dan (Türkiye) ilk kez kaydedilen Ethmia candidella (Alphéraky, 1908) örnekleri, Atatürk Üniversitesi Kampüs'ünde bulunan Populus alba gövdelerindeki çatlak ve yarıklardan aspiratör ile 2017-2018 eylül ayında toplanmıştır. Toplam 21 dişi birey elde edilmiştir. Örnekler laboratuvarda disekte edilmiş ve dişi genital organları ve kanat slaytları hazırlanmıştır. E. candidella'nın dış morfolojisi ve dişi genitalyası ayrıntılı olarak tanımlanmıştır. Ayrıca, döllenmiş dişilerden mikroskop altında yumurtalar elde edilmiştir.

Anahtar Kelimeler: Lepidoptera, Ethmiidae, Ethmia candidella, dış morfoloji ve dişi genitalya, Erzurum, Turkey.

\footnotetext{
${ }^{1}$ Atatürk University, Faculty of Agriculture, Department of Plant Protection, Erzurum, Turkey, muhammedtatar.28@hotmail.com

${ }^{2}$ Atatürk University, Faculty of Agriculture, Department of Plant Protection, Erzurum, Turkey, gtozlu@atauni.edu.tr

${ }^{3}$ Mustafa Kemal University, Faculty of Art and Sciences, Department of Biology, Hatay, Turkey, eatay@mku.edu.tr

${ }^{1}$ https://orcid.org/0000-0002-8312-8434 ${ }^{2}$ https://orcid.org/0000-0002-7187-7825 ${ }^{3}$ https://orcid.org/0000-0002-5274-1025
} 


\section{Introduction}

The Ethmiinae subfamily is a microlepidopteran group consisted more than 350 species in seven genera worldwide. The Ethmia genus includes 47 species groups. It also includes many species that are not assigned to species groups (Wei et al., 2007). In Europe, 29 species had been recorded until recently (Domingo, et al., 2003).

The first checklist study of moths from Turkish was listed by Koçak and Kemal $(2006,2007)$. In studying of Koçak and Kemal $(2006,2007)$, a total of 4604 moth species were listed together with their synonymous and updated distributions. Later, Koçak and Kemal (2009) reported that the Turkey Lepidoptera fauna was 5128 species belonging to 76 families. In addition, a total of 764 lepidoptera species, 554 Heterocera and 210 Rhopalocera, belonging to the province of Erzurum, were listed by the same authors. In addition to this information, Ethmia genus has 24 species in Turkey in present, but the genus Ethmia was not recorded found in Erzurum (Koçak and Kemal, 2009).

The distribution of Ethmia candidella in Turkey; Bursa, Diyarbakır, Kars, Konya, Kahramanmaraş, Van, Kırıkkale (Koçak and Kemal, 2009), Siirt (Kayci et al., 2012), Bitlis (Kemal and Koçak, 2017a), Van (Bahçesaray) (Kemal and Koçak, 2017b), Hakkari (Kemal et al., 2020) (Figure 1).

The distribution of Ethmia candidella; Czech Republic, France, Spain, Italy, Switzerland, Austria, Hungary, Yugoslavia, Romania, Greece (Karsholt and Razowski, 1996), Russia, (Shovkoon, 2008), Indonesian (Kun, 2004), Morocco, Western Algeria, Macedonia, S. Russia, Asia Minor, Syria, Palestine, Iraq, Iran, Transcaspia, Tunisia, Turkestan (URL-1), Portuguese, Slovakia (URL-2), Syria (URL-3).

Asperugo procumbens, Borago officinalis, Cerinthe majör and Lithospermum purpurocaeruleum are given as the larval hosts of E. candidella in URL-1. Kemal and Koçak (2017) stated in their study in Van (Bahçesaray) that E. candidella adults fly at night in autumn and their larvae hide under Boraginaceae (Echium, Anchusa) in spring.

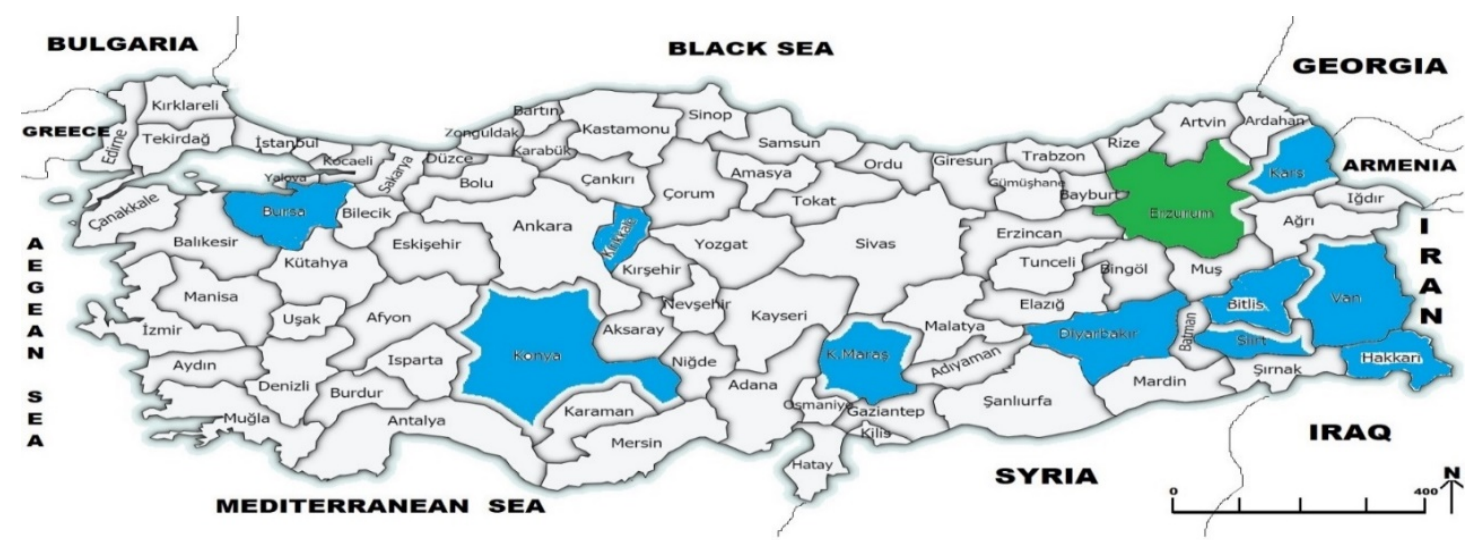

Figure 1. Distribution of Ethmia candidella (Alphéraky) in Turkey 


\section{Materials and Methods}

\subsection{Field Studies}

Field studies was carried out in the Atatürk University Campus (1850 m) in September 20172018. All the field works were done under suitable weather conditions (without strong winds and precipitation), and started early in the morning and continued until sunset. Ethmia candidella specimens was collected with aspiratör on Populus alba (Figure 7a, b). In the field studies, totally 21 specimens were obtained (Figure 7c).

\subsection{Laboratory Studies}

The specimens collected first were classified according to their body size without losing their body water. They were pinned to size 1 or 2 insect needles on special stretch boards and the front and rear pairs of wings were stretched in the laboratory. Stretched specimens were kept for fourteen days (two weeks) in a dark and dry place at room temperature to dry. After the morphological examinations and measurements of the female samples, the female genital organ was prepared for the identification of the species. The needling of the butterflies, stretching of the wings and genital organ preparations were made according to Atay (2006). The major taxonomic characters were described. Important morphological organs of E. candidella were photographed and drawn. The specimens were stored in the Biology Department of Mustafa Kemal University and Atatürk University, Faculty of Agriculture, Department of Plant Protection.

\section{Results and Discussion}

Genus: Ethmia Hübner, [1819]

Syn: Psecadia Hübner, [1825]; Anesychia Hübner, [1825]; Melanoleuca Stephens, 1829; Aedia Duponchel, 1837 nec Hübner, [1825]; Wiltshirea Amsel, 1949 nec Buckman, 1904 (Koçak and Kemal, 2009)

Ethmia candidella (Alphéraky, 1908)

Syn: orientella Caradja, 1931

\section{Material Examined}

Erzurum (Atatürk University Campus), 21.IX.2017 5q; 27.IX.2017 3ㅇ; (3954'11" N; 41¹4'59" E, 1850 m); 23.IX.2018 6우 28.IX.2018 7우 (3954'11" N; 41¹4'59" E, 1850 m).

\section{Measurements}


Body Length $9: 8,5-10,5(9,6) \mathrm{mm}$, wingspan 23-28 $(26,1) \mathrm{mm}$.

Female (Figure 2): On the head vertex, frons and antennae blackish gray; labial palpus, maxillary palpus and haustellum gray. On the vertex, frons, labial palpus, maxillary palpus and haustellum are densely covered smooth scales (Figure 3a). Head 1,75 times wider than its length. Antennae filiform and long, length $9 \mathrm{~mm}$, densely covered with short cillia, its length 0,69 times longer than forewing length. Labial palpus long and well developed, strongly recurved upwards (Figure 3b). Its length 1,70 times as long as ocular diameter. The first labial segment is slight oblique and long. The second segment is long, strongly oblique upwards. The third segment is the same length as the first segment. Maxillary palpus with small 4 segments, rather short and thin and last segment (fourth segment) longest. Haustellum is very long, its length as long as antennae length. Eyes are round, large and dark brown. Ocelli and chaetosemata absent. Forewings are long, narrow and ovalshaped, its outer margin convexly curved, its length 2,71 times longer than its width. Surface of the forewings white, with blackish spot. Under surface of the forewings more dull blackish gray colored. Hindwings long and broad, its length 2,12 times longer than its width. Upper surface of the hindwings white and plain, and its apex light grayish. Under surface of the hindwings similar to the upper surface. Forewings 13 veined, with 2 anal veins. Hindwings 10 veined, with 3 anal veins (Figure $3 c$ ). Thorax with 5 back dots.

\section{Female Genitalia}

Papillae analis (ovipositor) is heavily sclerotized, long and slightly broad, with short and sparse setose. Apophyses posteriores long and thin; slightly longer than papillae analis. Segment VIII is sclerotized broad and medium length. Apophyses anteriores largely reduced. Antrum sclerotized long and narrow. Ductus bursae is extremely long, tubular and membranous. Corpus bursae rather big and broad, membranous with signum. Signum large and long, a spiny plate, subrhombic, and covered with more or less uniform teeth (Figure 4). 


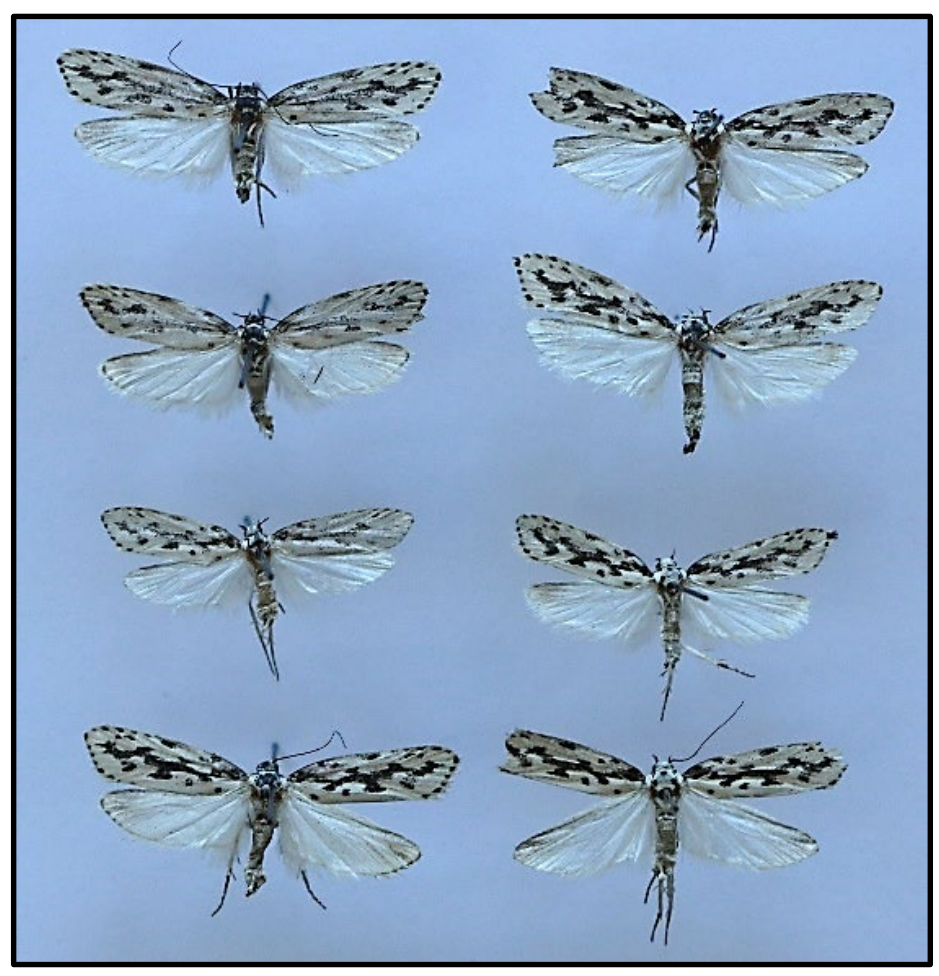

Figure 2. Adult females of Ethmia candidella

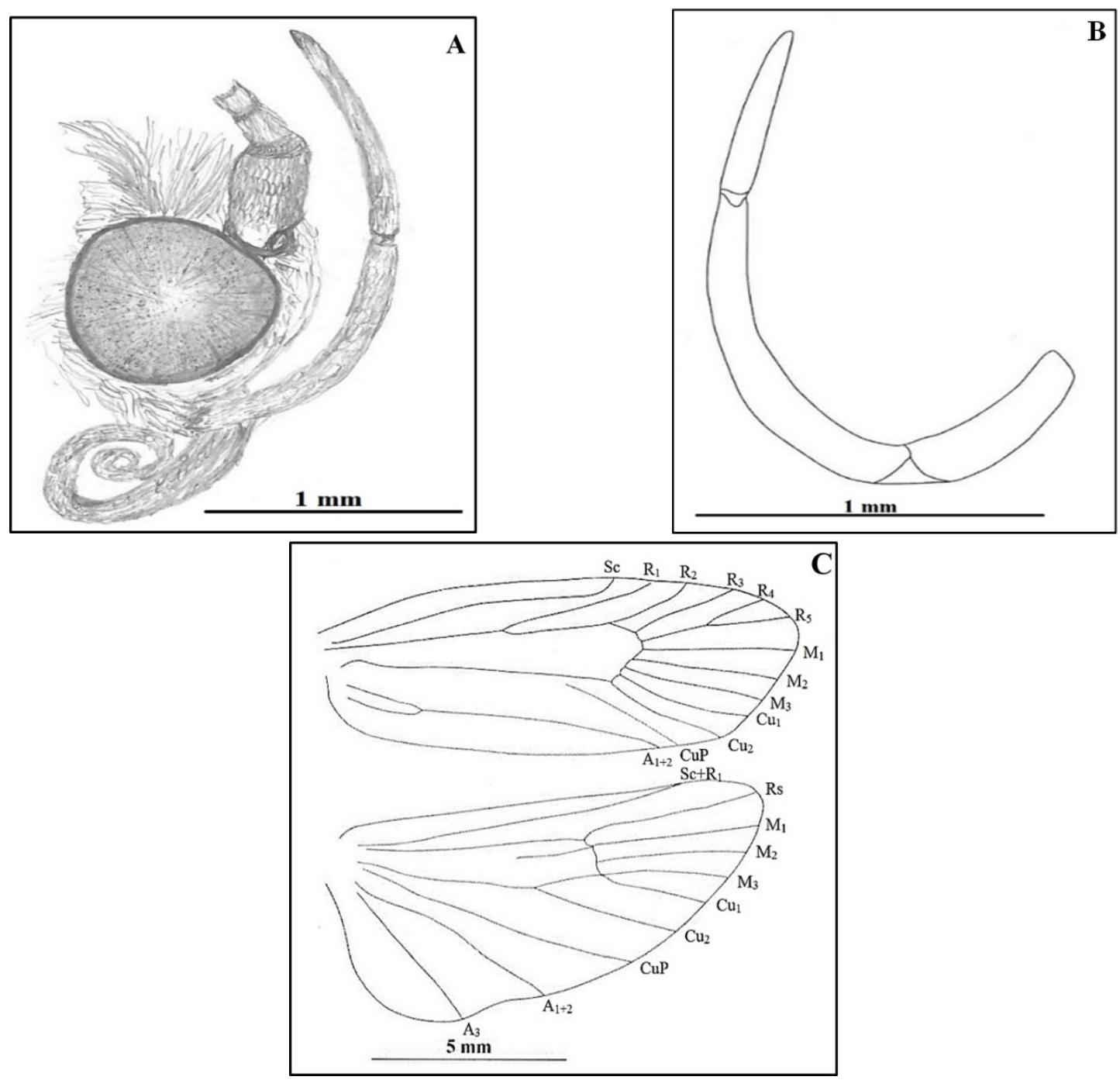


Figure 3. A) The head structure of Ethmia candidella; B) The labial palpus of Ethmia candidella;

C) The veins of the forewing and hindwing
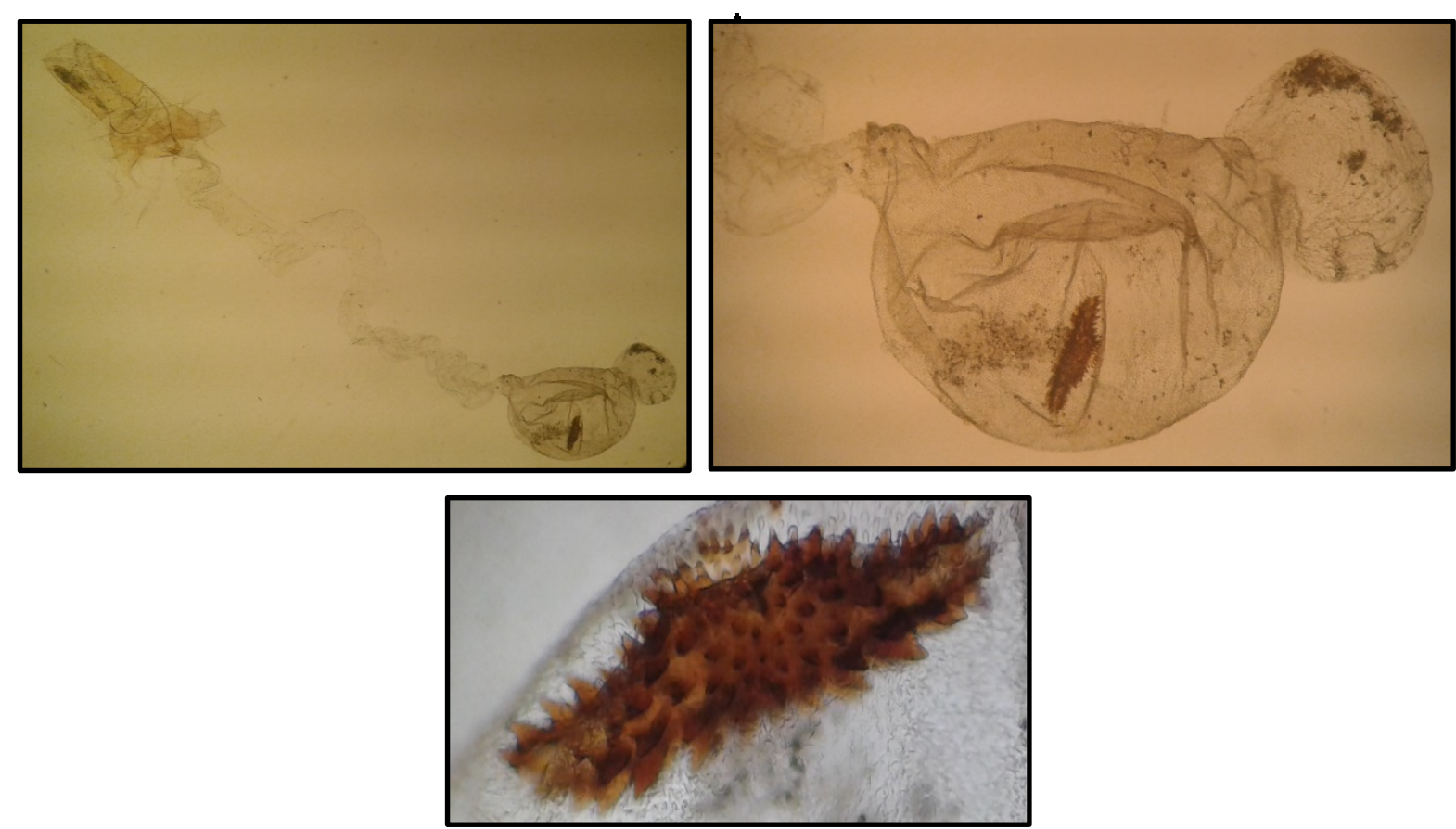

Figure 4. The female genitaliae of Ethmia candidella (General structure, corpus bursae and signum)

In addition, pictures of eggs obtained from fertilized females were taken under the microscope (Figure 5). Pictures of mature larvae and pupa of E. candidella are also given in order to present all the periods of the species in an integrity (a holistic manner) (Figure 6).
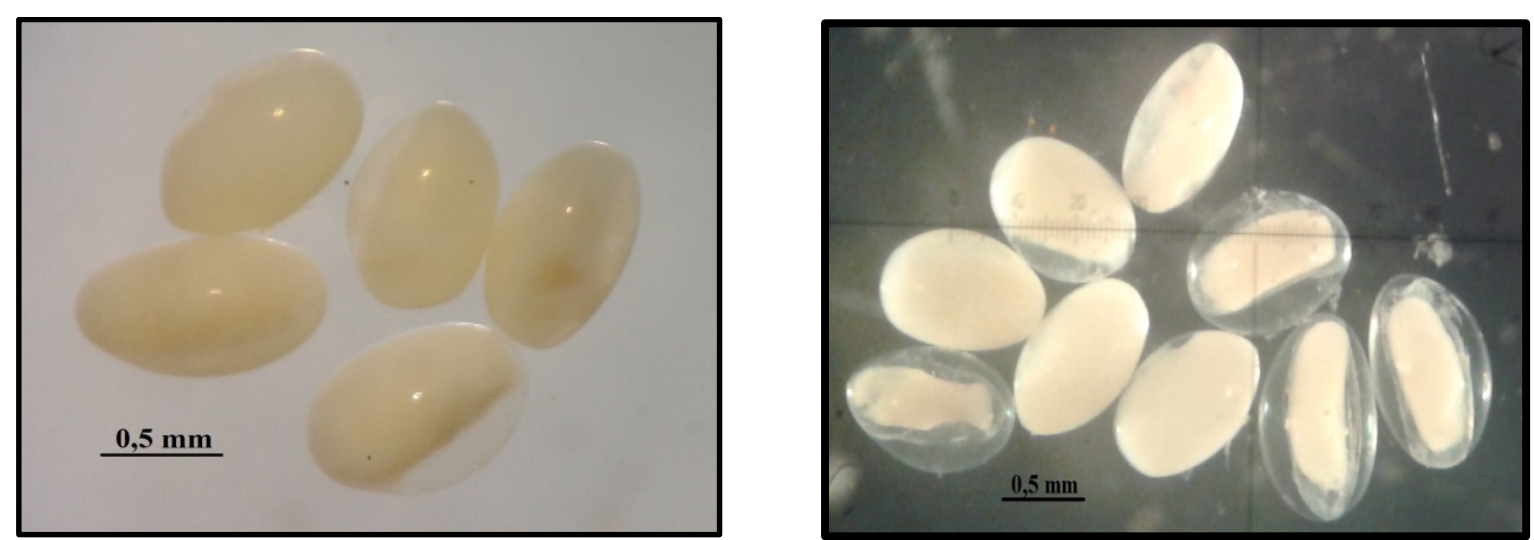

Figure 5. Appearance of Ethmia candidella eggs under the microscope 

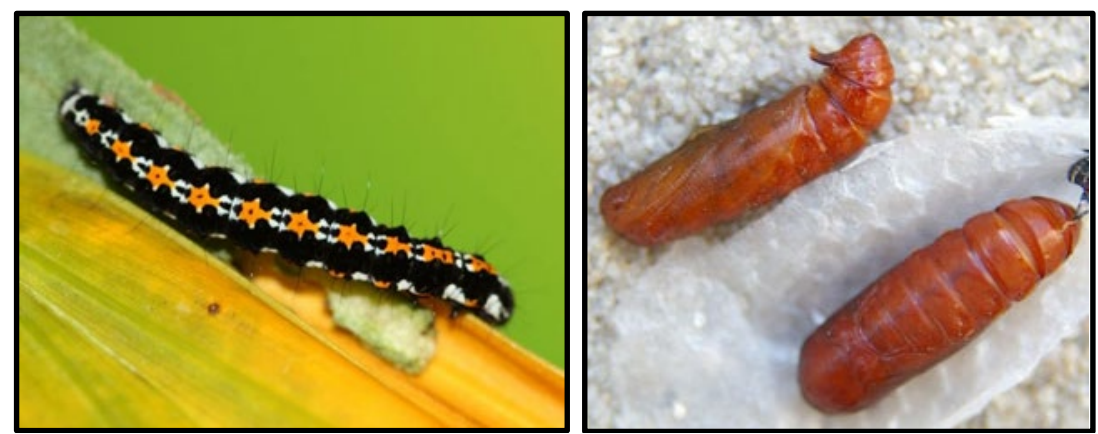

Figure 6. Larvae (URL-4) and pupae of Ethmia candidella (URL-5)

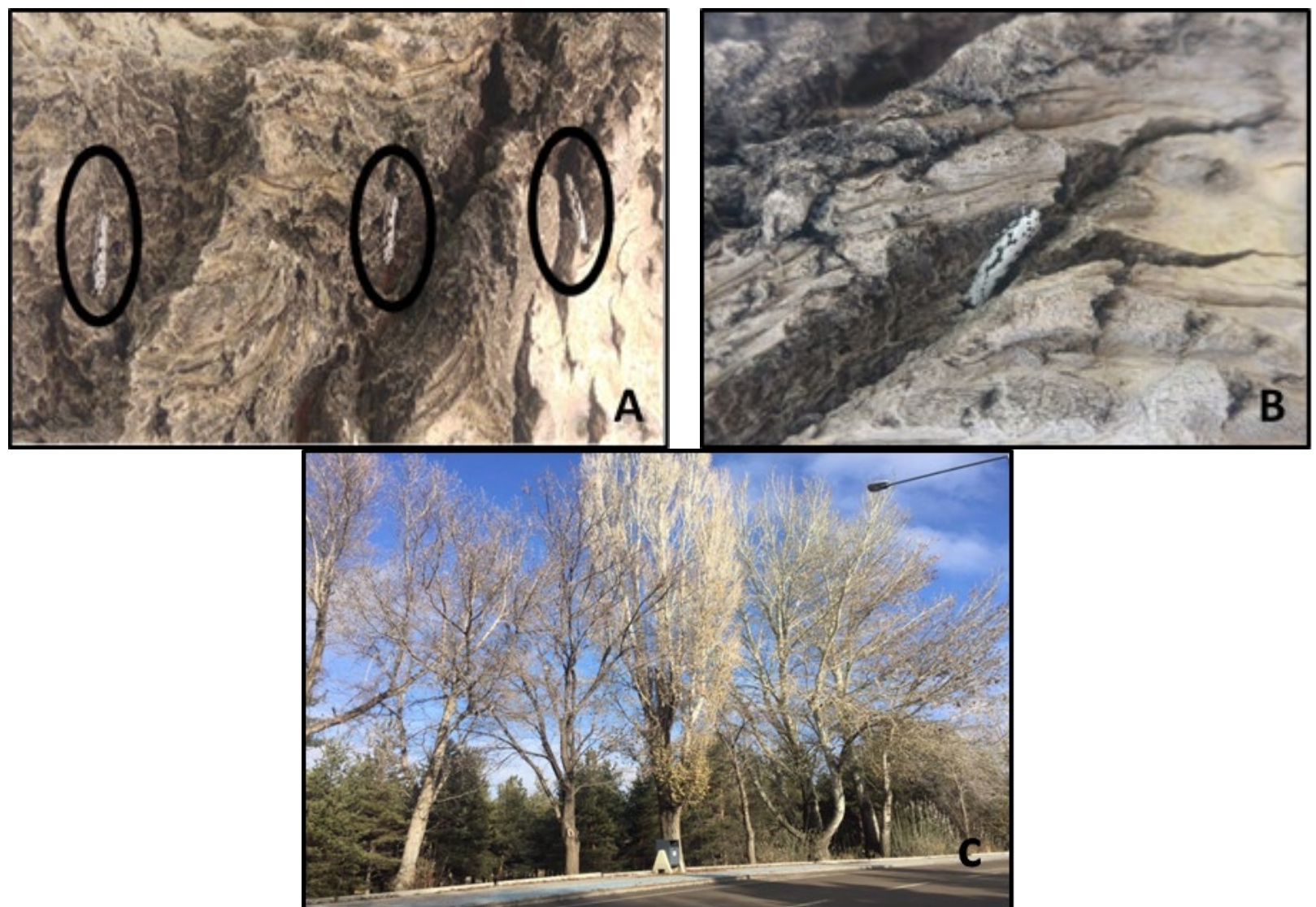

Figure 7. a, b) Ethmia candidella adults in cracks and crevices on Populus alba, c) The study area of the samples obtained

\section{Conclusions and Recommendations}

This species is new record for the the lepidoptera fauna of Erzurum. In this study, identified the genital and external morphology of the female E. candidella. The important taxonomic characters of E. candidella were redefined in detail by comparasion of different parameters with each other. Each one of the genital and external taxonomic characters were measured with sterio microscope and digital caliper. All individuals of the insect were obtained towards the end of September and consist of completely fertilized females. This situation shows us that the species hibernated the winter in the egg stage. The bioecology of the species should be revealed with more detailed studies in the future. 


\section{Authors' Contributions}

All authors contributed equally to the study.

\section{Statement of Conflicts of Interest}

There is no conflict of interest between the authors.

\section{Statement of Research and Publication Ethics}

The author declares that this study complies with Research and Publication Ethics.

\section{References}

Atay, E. (2006). The Identity of Parapoynx affinialis (Guenee, 1854) (Lepidoptera, Crambidae, Nymphulinae) in Turkey. Journal of Entomology, 3(1), 76-81.

Domingo, J., Huemer, P., and Baixeras J. (2003). Ethmia penyagolosella sp. n. (Lepidoptera: Ethmiidae), A New Species From Spain. Nachr. Entomol., 24(4), 183-188.

Koçak, A.Ö., and Kemal, M. (2006). Checklist of the Lepidoptera of Turkey. Centre for Entomological Studies, 1, 1-196.

Koçak, A.Ö., and Kemal, M. (2007). Revised and annotated checklist of the Lepidoptera of Turkey. Centre for Entomological Studies, 8, 1-150.

Koçak, A.Ö., and Kemal, M.. (2009). Revised checklist of the Lepidoptera of Turkey. Centre for Entomological Studies, 17, 1-150.

Karsholt, O., and Razowski, J. (1996). The Lepidoptera of Europe A Distributional Checklist. Apollo Books. Denmark, $380 \mathrm{pp}$.

Kayci, L., Karabacak, O., and Akın, K. (2012). Ethmia candidella (Alphéraky, 1908) Türünün Biyolojisi ve Yayılışı Üzerine Bir Araştırma (Lepidoptera, Ethmiidae). 21. Ulusal Biyoloji Kongresi (p.1018-1019). İzmir: Ege Üniversitesi.

Kemal, M., and Koçak, A. Ö. (2017 a). Annotated list of moths of Süphan Volcano (Bitlis Province, East Turkey) (Lepidoptera). Centre for Entomological Studies, 1 (2), 124.

Kemal, M., and Koçak, A. Ö. (2017 b). On some Microlepidoptera of Bahçesaray district (Van Province, East Turkey) (Lepidoptera). Centre for Entomological Studies, 15 (3), 124.

Kemal, M., Kızıldağ, S., and Koçak A.Ö. (2020). Illustrated list of the Lepidoptera species of Zap valley (Hakkari Province, South East Turkey). Centre for Entomological Studies, 19(2), 147.

Kun, A. (2004). A Review of The Ethmia lineatonotella Species Group, With Description of Two New Species (Lepidoptera, Ethmiidae). Acta Zoologica Academiae Scientiarum Hungaricae, 50(4), 337-351.

Shovkoon, D. F. (2008). On The Rediscovery of Ethmia discrepitella (Rebel, 1901) With Remarks on Brachyptery in Females of Ethmia (Ethmiidae). Nota Lepidopterologica, 31(2), 215-221.

URL-1 https://en.wikipedia.org/wiki/Ethmia candidella (Accessed Date:16 December 2020).

URL-2 https://fauna-eu.org/cdm dataportal/taxon/8ab305bf-f354-4a7c-8daf-36fc58527fab, (Accessed Date:16 December 2020).

\section{URL-3}

https://web.archive.org/web/20121103180218/http://www.nic.funet.fi/pub/sci/bio/life/insecta/ lepidoptera/ditrysia/gelechioidea/oecophoridae/ethmiinae/ethmia/index.html, (Accessed Date:16 December 2020). 
URL-4: http://dogalhayat.org/property/ethmia-candidella/, (Accessed Date:17 December 2020).

URL-5: https://lepidoptera.eu/species/3885, (Accessed Date:17 December 2020).

Wei, C. H., Kun, A., and Yen, S. H. (2007). A Preliminary Analyses of The Phylogeny of The Ethmiidae Moths (Lepidoptera: Gelechioidea) With Special Reference to The Evolutionary Patterns Host Use. Acta Zoologica Academiae Scientiarum Hungaricae, 50(Suppl. 1), 61-100. 